\title{
REDUCING THE SPORTS INJURY THROUGH FUNCTION MOVEMENT BIOLOGICAL IMAGE DATA SCREENING
}

\author{
REDUZINDO LESÕES ESPORTIVAS POR MEIO DA TRIAGEM DE DADOS BIOLÓGICOS DE IMAGENS \\ DEMOVIMENTO
REDUCCIÓN DE LAS LESIONES DEPORTIVAS MEDIANTE LA DETECCIÓN DE DATOS BIOLÓGICOS POR IMÁGENES EN MOVIMIENTO

Shuyun Zhu' (DD
(Physical Education Professional)

1. School of Sports and Health, Guangdong Polytechnic of Science and Technology, Zhuhai, China.

\section{Correspondence:}

School of Sports and Health, Guangdong Polytechnic of Science and Technology, Zhuhai, 519090, China.a15915885722@163.com

\begin{abstract}
Introduction: Among the many cases of sports injuries, the incidence of musculoskeletal injuries remains high. After a musculoskeletal injury occurs, athletes often need to suspend training and undergo rehabilitation. A suitable sport mode requires athletes to have sufficient joint range of motion, core stability, and balance ability in different positions to complete various complex movements in training and competition. Objective: The paper analyzes the impact of warm-up exercises before the test on the test results of functional sports biological image data screening (FMS ${ }^{T M}$ ) and provides references for unifying test conditions, checking the reliability of FMS ${ }^{T M}$ repeated tests, and discussing the comparability of the research results. Methods: The paper used the same password and process to test 12 young male volleyball professional athletes without warm-up and warm-up. The two-dimensional motion analysis system Dartfish Pursuit 8.0 was used to analyze the video data recorded by the two cameras simultaneously. Results: In the two tests before and after, the hurdle step score $(1.75 \pm 0.62$ vs. $2.42 \pm 0.52)$ and the total score (13.50 \pm 2.20 vs. $16.42 \pm 2.15)$ were significantly higher than those without the warm-up test $(P<0.01)$. Besides, in squats ( $1.58 \pm 0.67$ vs. $1.92 \pm 0.67)$, straight lunges $(2.00 \pm 0.43$ vs. $2.50 \pm 0.52)$, active straight leg lifts (1.50 \pm 0.67 vs. $2.00 \pm 0.60)$, rotation stability (1.42) \pm 0.52 vs. 1.92 \pm 0.29$)$ showed a significant increase in the score $(\mathrm{P}<0.05)$. Conclusions: Warm-up exercises before the test can improve the test results. This abnormal movement pattern observed only by visual inspection may not truly reflect the "dysfunction" of the movement. In the case of ignoring the pre-test warm-up factors, feedback on sports performance and formulating training strategies, this conclusion of predicting injury risk and evaluating training effects may have specific limitations in its reference value. Level of evidence Il; Therapeutic studies - investigation of treatment results.
\end{abstract}

Keywords: Triage; Warm-Up Exercise; Sports Injury; Injury Risk.

\section{RESUMO}

Introdução: Dentre os diversos casos de lesões esportivas, a incidência de lesões musculoesqueléticas permanece elevada. Após a ocorrência de uma lesão musculoesquelética, os atletas geralmente precisam suspender o treinamento e se submeter à reabilitação. Um modo de esporte adequado requer que os atletas tenham amplitude de movimento articular suficiente, estabilidade central e capacidade de equilíbrio em diferentes posições para completar vários movimentos complexos em treinamento e competição. Objetivo: o artigo analisa o impacto dos exercícios de aquecimento antes do teste sobre os resultados dos testes de triagem de dados de imagens biológicas esportivas funcionais (FMS ${ }^{T M}$ ) e fornece referências para unificar as condições de teste, verificar a confiabilidade de testes FMS ${ }^{T M}$ repetidos e discutir a comparabilidade dos resultados da pesquisa. Métodos: O artigo utilizou a mesma senha e processo para testar 12 jovens atletas profissionais do sexo masculino de voleibol sem aquecimento e com aquecimento. O sistema de análise de movimento bidimensional Dartfish Pursuit 8.0 foi usado para analisar os dados de vídeo gravados pelas duas câmeras simultaneamente. Resultados: Nos dois testes antes e depois, a pontuação do hurdle step (1,75 $\pm 0,62$ vs. 2,42 $\pm 0,52)$ e a pontuação total (13,50 $\pm 2,20$ vs. 16,42 $\pm 2,15)$ foram significativamente maiores do que aqueles sem o teste de aquecimento ( $P<0,01)$. Além disso, em agachamentos $(1,58 \pm 0,67 \mathrm{vs} .1,92 \pm 0,67)$, estocadas retas

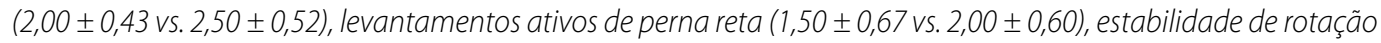
$(1,42) \pm 0,52$ vs. 1,92 $\pm 0,29)$ mostrou um aumento significativo na pontuação $(P<0,05)$. Conclusão: Os exercícios de aquecimento antes do teste podem melhorar os resultados do teste. Este padrão de movimento anormal observado apenas por inspeção visual pode não refletir verdadeiramente a "disfunção" do movimento. No caso de ignorar os fatores de aquecimento pré-teste, feedback sobre o desempenho esportivo e formulação de estratégias de treinamento, esta conclusão de prever o risco de lesões e avaliar os efeitos do treinamento pode ter limitações específicas em seu valor de referência. Nível de evidência Il; Estudos terapêuticos - investigação dos resultados do tratamento.

Descritores: Triagem; Exercício de Aquecimento; Lesão Esportiva; Risco de Lesão.

\section{RESUMEN}

Introducción: Entre los muchos casos de lesiones deportivas, la incidencia de lesiones musculoesqueléticas sigue siendo alta. Después de que ocurre una lesión musculoesquelética, los atletas a menudo necesitan suspender 
el entrenamiento y someterse a rehabilitación. Un modo de deporte adecuado requiere que los atletas tengan suficiente rango de movimiento articular, estabilidad central y capacidad de equilibrio en diferentes posiciones para completar varios movimientos complejos en el entrenamiento y la competencia. Objetivo: El documento analiza el impacto de los ejercicios de calentamiento antes de la prueba en los resultados de las pruebas de detección de datos de imágenes biológicas deportivas funcionales (FMSTM) y proporciona referencias para unificar las condiciones de prueba, verificar la confiabilidad de las pruebas FMS ${ }^{T M}$ repetidas y discutir la comparabilidad de los resultados de la investigación. Métodos: El documento utilizó la misma contraseña y proceso para evaluar a 12 jóvenes atletas profesionales de voleibol sin calentamiento y con calentamiento. El sistema de análisis de movimiento bidimensional Dartfish Pursuit 8.0 se utilizó para analizar los datos de video grabados por las dos cámaras simultáneamente. Resultados: En las dos pruebas antes y después, la puntuación del paso de valla (1,75 $\pm 0,62$ frente a 2,42 $\pm 0,52$ ) y la puntuación total $(13,50 \pm 2,20$ frente a 16,42 $\pm 2,15)$ fueron significativamente más altas que aquellas sin la prueba de calentamiento ( $P<0,01)$. Además, en sentadillas $(1,58 \pm 0,67 \mathrm{vs} 1,92 \pm 0,67)$, estocadas rectas $(2,00 \pm 0,43 \mathrm{vs} 2,50 \pm 0,52)$, levantamientos activos de piernas rectas $(1,50 \pm 0,67 \mathrm{vs} 2,00 \pm 0,60)$, estabilidad de rotación $(1,42) \pm 0,52$ vs. 1,92 $\pm 0,29)$ mostró un aumento significativo en la puntuación $(P<0,05)$. Conclusión: Los ejercicios de calentamiento antes de la prueba pueden mejorar los resultados de la prueba. Este patrón de movimiento anormal observado solo por inspección visual puede no reflejar realmente la "disfunción" del movimiento. En el caso de ignorar los factores de calentamiento previos a la prueba, la retroalimentación sobre el rendimiento deportivo y la formulación de estrategias de entrenamiento, esta conclusión de predecir un riesgo de lesión y evaluar los efectos del entrenamiento puede tener limitaciones específicas en su valor de referencia. Nivel de evidencia Il; Estudios terapéuticos: investigación de los resultados del tratamiento.

\section{Descriptores: Triaje; Ejercicio de Calentamiento; Lesion deportiva; Riesgo de Lesiones.}

\section{INTRODUCTION}

Although many studies have explored the relationship between the body's basic movement patterns and the risk of injury, there may still be potential factors that may affect the test results. This study assumes that warm-up exercises before the test can improve test scores. ${ }^{1}$ If this hypothesis is true, the repeated test results may be biased if the pre-test warm-up conditions are inconsistent. The strategies for improving sports performance in many studies are worth considering. Therefore, the purpose of this research is to compare the test results of FMS ${ }^{T M}$ with and without warm-up, analyze the influence of warm-up exercises before the test on the test results, and provide for unifying test conditions, verifying the reliability of FMS ${ }^{T M}$ repeated testing, and discussing the comparability of the research results reference.

\section{METHOD}

\section{Research object}

This study selects 12 young male professional volleyball players as the research objects. All subjects had no musculoskeletal injuries and pain during the test, and we're in a routine training state. The basic information of the research object is shown in Table 1. Before implementing the test, the head coach of the sports team clarified the content and purpose of the study and signed an informed consent form.

\section{RESEARCH METHODS}

\section{Experimental design}

To determine whether the warm-up exercise before the test will affect the assessment's performance, this study designed a repeated test

Table 1. Basic information of athletes.

\begin{tabular}{c|c}
\hline Number of people & $\mathbf{1 2}$ \\
\hline Age (year old) & $16.17 \pm 0.72$ \\
\hline Height $(\mathrm{cm})$ & $194.17 \pm 5.88$ \\
\hline Weight $(\mathrm{kg})$ & $79.19 \pm 7.57$ \\
\hline Particular training time (month) & $26.00 \pm 14.09$ \\
\hline
\end{tabular}

program without warm-up and with the warm-up. To reduce the impact of other training on the test, the two tests in this study were arranged in the morning of two adjacent days. Before the first test, all athletes did not warm up in any form. Before the second test, the sports team's full-time coaches would warm-up following the pre-match warm-up plan. ${ }^{2}$ There were no other training tasks during the two tests. The test process is organized and implemented by two persons who have obtained the FMS ${ }^{T M}$ senior certificate and one assistant staff. The two tests use the same password and are carried out in strict accordance with the FMS ${ }^{T M}$ operational requirements.

The two tests were completed in the volleyball training hall, and the later video processing and data analysis were completed in the Sports Biomechanics Laboratory of the Research Center. Before the test, we explained to the athletes FMS ${ }^{T M}$ seven test action requirements in detail and performed action demonstrations so that all athletes are familiar with the action's essentials. ${ }^{3}$ Except for the password, there was no test-related feedback (score and deduction points) during the two tests. Three attempts are allowed for each test action, with about 10 s between each attempt and an interval of about 60 s between each test action.

Set up two cameras (SONY HDRFX-1000PAL 50Hz) on the test area's front and side to collect video data synchronously. After the test, we used the two-dimensional motion image analysis system Dartfish Pro suite 8.0 (Switzerland) to analyze the video data. During the scoring process, slow playback and repeated viewing of the video is allowed, and the points deducted for each test are recorded according to the scoring standard.

\section{Warm-up exercise}

The total time of warm-up exercise is about 30min. The order of implementation of the warm-up program is half-court run, in-situ jump (big character jump, cross squat jump, cross jump, half squat jump), joint activities (neck, shoulder, elbow, thoracic spine, hip, knee, ankle), Half-court marching exercises (dynamic stretching, pace exercises, sprint sprints, special moves), block jumps (individual, collective), spiking (positions 2 and 4), serving and receiving. 


\section{Detection of moving human body}

Motion detection is the basis of human motion recognition. Affected by light, shadow, etc., using 2D cameras to detect moving human bodies is still challenging. This article uses distance information, combined with the background difference method for moving human detection, to overcome the above shortcomings. ${ }^{4}$ The specific expression is shown in formula (1):

$$
D(x, y)=\left\{\begin{array}{cl}
D^{\prime}(x, y), & \left|D^{\prime}(x, y)-D_{b k}(x, y)\right|>\sigma_{t h} \\
0, &
\end{array}\right.
$$

In the formula, $D(x, y)$ is the distance image of the detected moving human body; $D^{\prime}(x, y)$ is the distance image of the current frame; is the preset distance threshold; $D_{b k}(x, y)$ is the distance image of the background frame. To construct the background model, assuming that the background is static, the average background method is used. Record the background distance image sequence when there is no moving human body, and calculate the average value of multiple background distance images as the background distance image $D_{b k}(x, y)$. Figure 1 shows the extracted distance contour image of the moving human body, $\sigma_{t h}$ is taken as 1.2.

\section{MULTI-LAYER MOTION HISTORY IMAGE AND R TRANSFORM}

\section{Historical images of traditional sports}

Motion history image is a global description method of human motion, and each pixel value is the equation of motion time on this pixel. Let $B(x, y, t)$ be the binary contour image sequence of the moving human body, then the calculation method of the motion history image $\hbar_{\tau}(x, y, t)$ is as shown in formula (2):

$$
\hbar_{\tau}(x, y, t)=\left\{\begin{array}{l}
\tau, \quad \text { when } B(x, y, t)-B(x, y, t-1) \neq 0 \\
\max \left(0, \hbar_{\tau}(x, y, t-1)-1\right), \text { other }
\end{array}\right.
$$

The formula $\tau$ is the length of the time window, that is, the number of frames of a motion video sequence, and represents the duration of the motion. It can be seen from formula (2) that the motion history image is a scalar grayscale image, and the area with high brightness indicates the area where the latest motion occurred. As time progresses, the gray value of the old information in the MHI becomes smaller and becomes a darker pixel.

\section{Multi-layer motion history image}

It can be seen from formula (2) that MHI is obtained based on the binary contour image and only records the movement history generated by the movement parallel to the image plane and loses the movement information perpendicular to the image plane. Using distance information, MLMHI compresses all spatiotemporal distance information into motion energy map (MEI), forward multi-layer motion history image (fMLMHI) and backward multi-layer motion history image (bMLMHI) according to the amount of distance change. The exercise energy map represents the area where exercise occurs. FMLMHI characterizes the history of forwarding motion, that is, the increase in distance. bMLMHI characterizes the backward movement history, that is, the decrease in distance. According to the human body's structural characteristics and the self-occlusion characteristics of the human body movement, an appropriate threshold is selected. The human body movement is represented by the movement energy map plus two layers of movement history images before and after, denoted as $\hbar_{M L}=\left\{E_{\tau}, \hbar_{\tau}^{f 1}, \hbar_{\tau}^{f 2}, \hbar_{\tau}^{b 1}, \hbar_{\tau}^{b 2}\right\}_{b 1}$ The calculation formulas for the motion history images $\hbar_{\tau}^{f 1}$ and $\hbar_{\tau}^{b 1}$ of the first layer forward and the first layer backward are shown in equations (4) and (5):

$$
E_{\tau}(x, y, t)=\left\{\begin{array}{l}
\tau, \quad \text { when } D(x, y, t) \neq 0 \\
\max \left(0, E_{\tau}(x, y, t-1)-1\right)
\end{array}\right.
$$

$\mathbf{h}_{\tau}^{f 1}(x, y, t)=\left\{\begin{array}{l}\tau, \quad D(x, y, t)-D(x, y, t-1) \in[0.1,0.4) \\ \max \left(0, \mathbf{h}_{\tau}^{f 1}(x, y, t-1)-1\right)\end{array}\right.$

$\mathbf{h}_{\tau}^{b 1}(x, y, t)=\left\{\begin{array}{l}\tau, \quad D(x, y, t)-D(x, y, t-1) \in(-0.4,-0.1] \\ \max \left(0, \mathbf{h}_{\tau}^{b 1}(x, y, t-1)-1\right)\end{array}\right.$

In formulas (3)-(5), $E_{\tau}(x, y, t)$ is the movement energy diagram, which can be regarded as the overall movement information of human body movement. $\hbar_{\tau}^{f 1}$ and $\hbar_{\tau}^{b 1}$ respectively represent the movement history of forwarding and backward distance changes between 0.1 and 0.4 , that is, local movement information with small distance changes. The distance thresholds of $\hbar_{\tau}^{f 2}$ and $\hbar_{\tau}^{b 2}$ are respectively $[0.4,+\infty)$ and $(-\infty,-0.4]$, which represent the local motion information with significant distance changes. Since the distance value obtained by the TOF camera will fluctuate slightly, the information of the distance change $[0,0.1)$ is not included in the multi-layer motion history image. Like traditional $\mathrm{MHI}$, the brighter area in MLMHI represents the area where the movement has recently occurred.

\section{R transform}

Traditional MHI motion recognition often uses Hu invariant moments as shape descriptors. However, Hu moments are more sensitive to noisy shapes or unconnected shapes. Therefore, this paper uses R transform to

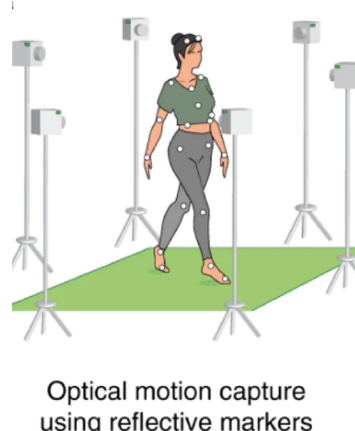

using reflective markers

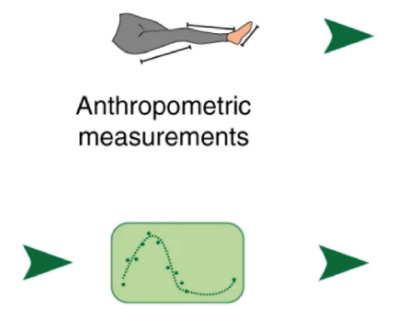

Semi-manual data processing
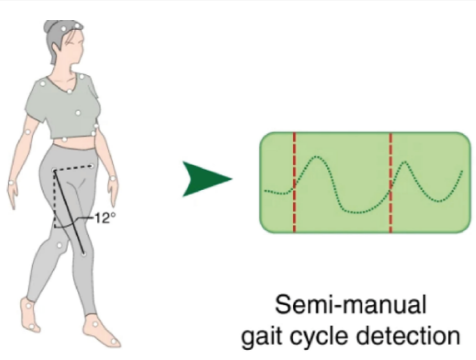

Semi-manual gait cycle detection

Figure 1. Moving human detection based on distance image. 
extract features of MLMHI. R transform is a new shape feature descriptor defined based on Radon transform. It has a low computational cost and can effectively describe shapes that are not connected or have holes. Mark an image as $f(x, y)$, and each point on the image is projected into a Radon matrix, then the Radon transformation is defined as for formula (6):

$$
R(\rho, \theta)=\int_{-\infty}^{+\infty} \int_{-\infty}^{+\infty} f(x, y) \delta(x \cos \theta+y \sin \theta-\rho) d x d y
$$

In the formula $\delta$ is the Dirac $\delta$-equation, $\rho \in[-\infty,+\infty]$, $\theta \in[0, \pi]$. On this basis, the R transformation is shown in equation (7), which is the sum of the square of the Radon transformation along a certain angle. Normalize it to get formula (8):

$$
R(\theta)=\int_{-\infty}^{+\infty} R^{2}(\rho, \theta) d \rho
$$

$$
R^{\prime}(\theta)=\frac{R(\theta)}{\max _{\theta}(R(\theta))}
$$

We perform $\mathrm{R}$ transformation on each layer of MLMHI to obtain a 180-dimensional feature vector. In this way, a total of 900-dimensional feature vectors are obtained for each motion sequence.

\section{Statistical analysis}

We use the FMS ${ }^{T M}$ scoring standard to evaluate the test actions recorded in the video. In addition to assessing each action score, we also record the number of athletes whose sport mode changes before and after the two tests according to the scoring standard. We use the Wilcoxon signed-rank test to analyze the difference between the two tests before and after. Statistical analysis was done using IBM SPSS 20, $\mathrm{P}<0.05$ indicated a statistically significant difference.

\section{RESULTS}

\section{$F M S^{T M}$ test score}

The results of the study (Table 2) show that compared with no warm-up test, the HS score of 12 athletes increased from $(1.75 \pm 0.62)$ to $(2.42 \pm 0.52)$ after warm-up, and the total score FMS ${ }^{T M}$ increased from (13.50 \pm 2.20$)$ to (16.42 \pm 2.15$)$ with very significant statistical significance $(P<0.01)$. The DS, $\mathrm{I}-\mathrm{LL}, \mathrm{ASL}$, and RS scores were significantly improved $(\mathrm{P}<0.05)$.

The scores of each action in the two tests are shown in Figure 2. Compared with the non-warm-up test, two athletes in SM increased, 3 in TSP-U increased in scores, 4 in DS increased in scores, I-LL, ASL There are 6 points increase in each with RS, and 8 points increase in HS. Moreover, the athletes who did not improve in each action score in the two tests were consistent.

Table 2. No warm-up and warm-up FMSTM test each action score and total score.

\begin{tabular}{c|c|c}
\hline Test & No warm-up & Warm-up \\
\hline DS & $1.58 \pm 0.67$ & $1.92 \pm 0.67 \mathrm{a}$ \\
\hline HS & $1.75 \pm 0.62$ & $2.42 \pm 0.52 \mathrm{a}$ \\
\hline I-LL & $2,000 \pm 0.43$ & $2.50 \pm 0.52 \mathrm{a}$ \\
\hline SM & $2.67 \pm 0.65$ & $2.83 \pm 0.58$ \\
\hline ASL & $1.50 \pm 0.67$ & $2,000 \pm 0.60 \mathrm{a}$ \\
\hline TSP-U & $2.58 \pm 0.52$ & $2.83 \pm 0.39$ \\
\hline RS & $1.42 \pm 0.52$ & $1.92 \pm 0.29 \mathrm{a}$ \\
\hline FMSTM total score & $3.50 \pm 2.20$ & $16.42 \pm 2.15 \mathrm{a}$ \\
\hline
\end{tabular}

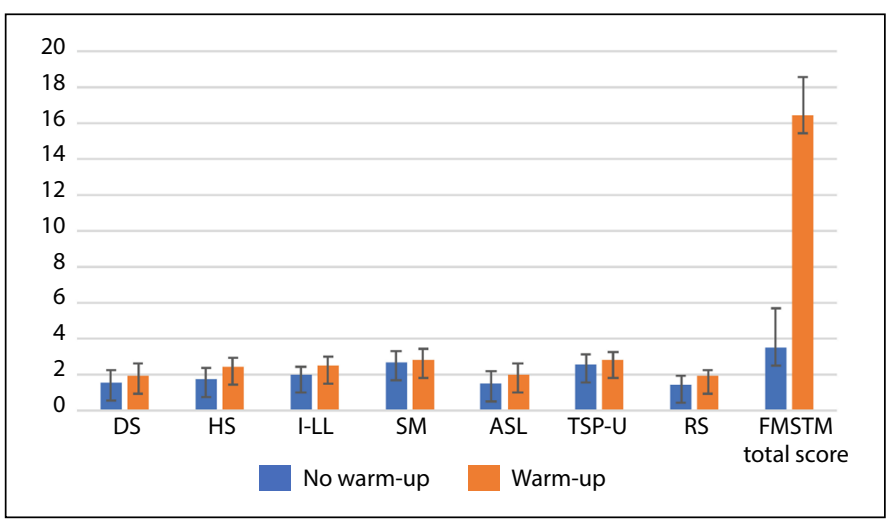

Figure 2. No warm-up and warm-up test each action score.

\section{DISCUSSION}

The results of this study should draw attention to the reliability of repeated testing. Studies have shown that the repeated test has high reliability within one $h$ to 7 days. test results may be affected by many external factors, such as the athlete's understanding of the test action, training before the test, execution motivation, scoring standards, etc. Whether the warm-up exercise before the test will affect the test results and how it will affect has not been reported. The results of this study show that warm-up exercises before the test can improve the score. Therefore, when carrying out the repeat test, warming up before the test should be considered.

At the same time, this study's results should draw attention to the consistency of experimental conditions. Consistent test conditions, credible and effective results are the prerequisites for comparative analysis of many research results. In sports, sports assessment and pre-match screening are widely used to analyze the physical condition of athletes. When using methods such as that rely solely on visual observation for evaluation, the research conditions' control is crucial. However, in the existing research, whether to warm up before the test is not uniform. Some studies clearly stated that there was no warm-up exercise before the test. Some studies clearly stated that the warm-up exercise was organized by a professional physical coach before the test. Still, most studies did not mention the warm-up exercise. This study found that the warm-up exercise before the test can have an impact on the test results. Thus, in the case of ignoring warm-up factors, direct feedback or coaching training on observed sports performance, this conclusion of assessing the risk of injury and evaluating the training effect is worth discussing. In addition to predicting injury risk, coaching training is another important application of testing, and many studies have analyzed the effects of coaching training. Studies have shown that four weeks of intervention training can significantly improve martial arts athletes' test results; 8 weeks of intervention training can significantly improve professional football players' test results; 12 weeks of intervention training can fire fighters'action patterns and significantly improve the test results. If the prerequisite of whether to warm up is not clear, these research results will lose their reference significance.

\section{CONCLUSION}

Warm-up exercises before the test can improve the results of the FMS TM test. This abnormal movement pattern observed only by visual inspection may not truly reflect the "dysfunction" of the movement. In the case of ignoring the pre-test warm-up factors, feedback on the observed sports performance and formulating training strategies, this conclusion of predicting the risk of injury and evaluating the training effect may have specific limitations in its reference value. Regardless of whether FMS ${ }^{T M}$ can predict the risk of injury, this study suggests 
that the follow-up work of this type of test should not only focus on improving the test results but should deal with the relationship between the scoring standard and the injury mechanism hidden by the complex movement in sports and particular occupations, and the test results with injury Further research on the relationship between physical conditions at the time.

The author declare no potential conflict of interest related to this article

AUTHORS' CONTRIBUTIONS: The author made significant contributions to this manuscript. Shuyun Zhu: writing and performing surgeries; data analysis and performing surgeries; article review and intellectual concept of the article

\section{REFERENCES}

1. Chałubińska D, Truszczyńska-Baszak A, Reszelewska A, Targosiński P, Rekowski W. Twelve-week sensorimotor training as a factor influencing movement patterns of canoe slalom athletes, assessed by the Functional Movement Screen. Biomedical Human Kinetics. 2020 [cited 202114 Jun];12(1):10-6. Available from: https://sciendo.com/article/10.2478/bhk-2020-0002

2. Steinberg N, Adams R, Ayalon M, Dotan N, Bretter S, Waddington G. Recent ankle injury, sport participation level, and tests of proprioception. J Sport Rehabil. 2019;28(8):824-30.
3. Pender SC, Smith AM, Finnoff JT, Huston J 3rd, Stuart MJ. Concussions in ice hockey - moving toward objective diagnoses and point-of-care treatment: a review. Curr Sports Med Rep. 2020;19(9):380-6.

4. Read P, Mc Auliffe S, Wilson MG, Myer GD. Better reporting standards are needed to enhance the quality of hop testing in the setting of $\mathrm{ACL}$ return to sport decisions: a narrative review. Br J Sports Med. 2021;55(1):23-9. 